\title{
Monitoring of Newcastle disease in poultry at migratory birds landing sites: Manque Seco and Cacha Pregos between 2013 and $2014^{*}$
}

\section{Monitoramento da doença de Newcastle em aves domésticas nos sítios de pouso de aves migratórias: Mangue Seco e Cacha Pregos entre 2013 e 2014}

\author{
Marcos Santos Prinz' ${ }^{1}$ (D) (https://orcid.org/0000-0002-0387-2918) \\ Bruno Passos Fernandes ${ }^{* *}$ (D) (https://orcid.org/0000-0002-4465-6402) \\ Jorge Raimundo Lins Ribas ${ }^{1}$ (D) (https://orcid.org/0000-0001-6142-4059) \\ Maíra Pessoa Jornane Barbosa Santos ${ }^{1}$ (D) (https://orcid.org/0000-0002-0664-8436) \\ Iram da Silva Ferrão ${ }^{1}$ (D) (https://orcid.org/0000-0002-3871-133X) \\ Rui Ferreira Leal ${ }^{1}$ (D) (https://orcid.org/0000-0002-1134-0196) \\ Verena Maria Mendes de Souza1 (D) (https://orcid.org/0000-0001-9675-0735) \\ Robson Bahia Cerqueira² (D) (https://orcid.org/0000-0001-5054-0353)
}

\begin{abstract}
The poultry industry has been considered one of the most efficient agricultural activities, placing Brazil in the ranking of the largest producers of chicken meat. However, a threat to the poultry production chain is the entrance of Newcastle disease virus (NDV) in the country, which would bring huge economic and social losses. Monitoring of the virus was conducted in domestic poultry (Gallus gallus domesticus) farms on the migratory birds landing sites Mangue Seco and Cacha Pregos between 2013 and 2014 to control Newcastle disease (NCD) in these locations. Activities in health education, filling the questionnaire to define the sanitary profile of the farms, georeferenced registration and collection of blood samples, cloacal and tracheal swabs of the backyard birds were the epidemiological surveillance actions performed. A total of 133 serum samples were analyzed in Mangue Seco and 81 in Cacha Pregos. The results showed that both Mangue Seco (63.4\%) and Cacha Pregos $(88.9 \%)$ presented reactive animals for the NDV. The results of real-time polymerase chain reaction (RT-PCR) and viral isolation analyses were negative, proving that the domestic poultry were not eliminating the virus at the time of sample collection. The high percentage of reactive animals by indirect ELISA test in both epidemiological units studied suggests the presence of NDV circulating lentogenic strain, since there was no death registration and the birds did not have characteristic symptoms of the disease.
\end{abstract}

KEYWORDS: ELISA; epidemiological surveillance; georeferencing; health education.

\begin{abstract}
RESUMO: A avicultura tem sido considerada uma das atividades agrícolas mais eficientes, colocando o Brasil no ranking dos maiores produtores de carne de frango. No entanto, uma ameaça à cadeia produtiva da avicultura é a entrada do vírus da doença de Newcastle (NDV) no país, o que acarretaria enormes prejuízos econômicos e sociais. $\mathrm{O}$ monitoramento do vírus foi realizado em granjas de aves domésticas (Gallus gallus domesticus) nos locais de desembarque de aves migratórias de Mangue Seco e Cacha Pregos entre 2013 e 2014 para controlar a doença de Newcastle (DCNT) nesses locais. Atividades de educaçáo em saúde, preenchimento de questionário para definição do perfil sanitário das fazendas, cadastro georreferenciado e coleta de amostras de sangue e swabs cloacal e traqueal de aves de quintal foram as açóes de vigilância epidemiológica realizadas. Um total de 133 amostras de soro foram analisadas em Mangue Seco e 81 em Cacha Pregos. Os resultados mostraram que tanto Mangue Seco (63,4\%) quanto Cacha Pregos (88,9\%) apresentaram animais reativos para o NDV. Os resultados da reação em cadeia da polimerase em tempo real (RT-PCR) e das análises de isolamento viral foram negativos, comprovando que as aves domésticas não estavam eliminando o vírus no momento da coleta das amostras. $\mathrm{O}$ alto percentual de animais reativos pelo teste ELISA indireto em ambas as unidades epidemiológicas estudadas sugere a presença de cepa lentogênica circulante de NDV, uma vez que não houve registro de óbito e as aves não apresentavam sintomas característicos da doença.
\end{abstract}

PALAVRAS-CHAVE: ELISA; vigilância epidemiológica; georreferenciamento; educação em saúde.

'Agência de Defesa Agropecuária da Bahia - Laboratório de Sanidade Animal - Salvador (BA), Brazil.

Universidade Federal do Recôncavo da Bahia - Hospital Universitário de Medicina Veterinária - Laboratório de Doenças Infectocontagiosas - Cruz das Almas (BA), Brazil. *This paper is part of the dissertation thesis of the first author.

**Corresponding author: brunofernandesnv@gmail.com

Received on: 3/18/2020. Accepted on: 8/27/2020 


\section{INTRODUCTION}

Newcastle disease (NCD) is an infection caused by a serotype- 1 aviary paramyxovirus (APMV-1). Highly contagious and many times lethal, this infirmity is of compulsory notification for the World Organization for Animal Health (OIE), being found across the globe. It strikes several bird species, of whom the domestic chicken is the most susceptible, which can compromise the poultry production chain with economic and social losses (ALEXANDER, 2003; OIE, 2019).

One of the natural means of introduction of the virus in Brazil is through the carrying of virulent strains by existent migratory birds. The considerable size of savage bird populations, the absence of frontiers, and the ease of migration of the migratory birds make this population be considered an extremely important vector of viral dissemination. The migratory bird's concentration sites are important for the epidemiological surveillance of countries, making it fundamental monitor these sites in order to detect possible entry routes of viruses into the country (THOMAZELLI, 2009; CEMAVE, 2015). In the state of Bahia, there are five stopping spots for migratory birds and their presence at the Bahia's coast indicates the existence of a huge coastal route. The Nearctic species show up at Bahia's coast in mid-October and stay there until the end of March, but some vacant representatives can stay longer.

This paper aims to characterize and monitor the epidemiological surveillance system at the landing sites of migratory birds of Mangue Seco and Cacha Pregos between 2013 and 2014, as a way of subsidizing the Agency for Agriculture and Livestock Defense of Bahia to prevent the introduction of Newcastle disease virus (NDV) in the domestic poultry production cycle of the state of Bahia.

\section{MATERIAL AND METHODS}

\section{Place of study}

The study was conducted at two epidemiological units: Mangue Seco and Cacha Pregos. The former is located at Jandaíra city, 527 kilometers away from Salvador. It is a sandy landmark that projects itself toward the ocean from the south margin of the Real River delta, extreme north of Bahia's coast, sharing boundaries with the state of Sergipe at the coordinates $11^{\circ} 27^{\prime} \mathrm{S}$ and $37^{\circ} 21^{\prime} \mathrm{W}$ (Fig. 1). The latter is located at the extreme south of Itaparica Island, at Vera Cruz municipality, around 128 kilometers from Salvador via ferry boat at the coordinates $13^{\circ} 07^{\prime} \mathrm{S}$ and $38^{\circ} 48^{\prime} \mathrm{W}$ (Fig. 1).

\section{Sampling}

The selection of creation points and the number of birds to compose the sample was performed using the criteria of bird number per breeding shack, according to the Technical Note of the Coordination of Aviary Sanity No. 16/2012, from the Brazilian Ministry of Agriculture, Livestock, and Supply (MAPA), as shown on Table 1. Based on Table 1 and due to the bird count of each property swinging around 4 animals, samples from 67 properties were collected, being 42 of Mangue Seco and 25 of Cacha Pregos, inspected over the 2 years of the experiment. Total blood samples and cloacal and tracheal swabs were collected from each bird, accomplishing 231 blood samples, 231 cloacal swabs, and 231 tracheal swabs. These samples were collected between 2013 and 2014, as shown in Table 2.

Initially, residencies with subsistence breeding shacks, spotted over a 25 -kilometers radius around the landing site of the migratory birds were identified. Then, a georeferenced registration of these breeding shacks was made, sampling the poultry that were likely to have contact with migratory birds. The research was aligned with activities aiming at Education in Health over schools and fishermen's associations. During the visits, the property owners were informed about the research objective and the importance of suspect case notifications, received orientations and clarifications about the infirmity, as well as biosecurity basic measures. The producers were interviewed using an epidemiologic-standardized inquiry to define the sanitary profile of the breeding shacks. Each questionnaire had the following requisites: the existence of other animal species at the property; internal and external bird commerce; use of animal transit guide; identification of subsistence breeding shacks; implementation of sanitary emptiness; implementation of birds' vaccination against Newcastle's; contact with migratory birds; discharge of birds in common trash. For georeferencing of breeding shacks, a GPS device was used to capture the reference points, then transferred to $\mathrm{i} 3 \mathrm{Geo}$, a freeware based on a composition of other freewares, mainly Mapserver.

\section{Collection of samples}

From 3 to $5 \mathrm{~mL}$ of blood were collected by puncturing the ulnar vein, located at the ventral surface of the birds' wing (Fig. 2). Posteriorly, the blood was centrifuged and the serum transferred to sterile Eppendorf-like tubes and identified by property. For the cloacal swab sampling, circular motions were made in the cloacal orifice (Fig. 3). Then, the tip of the swab on hand was cut and the rest of it dipped in the flask that had the means of transportation. For the tracheal swab, the bird beak was opened, the tongue was laid down, and the sterilized swab was introduced in the trachea. Two swabs by bird were used in the entire 


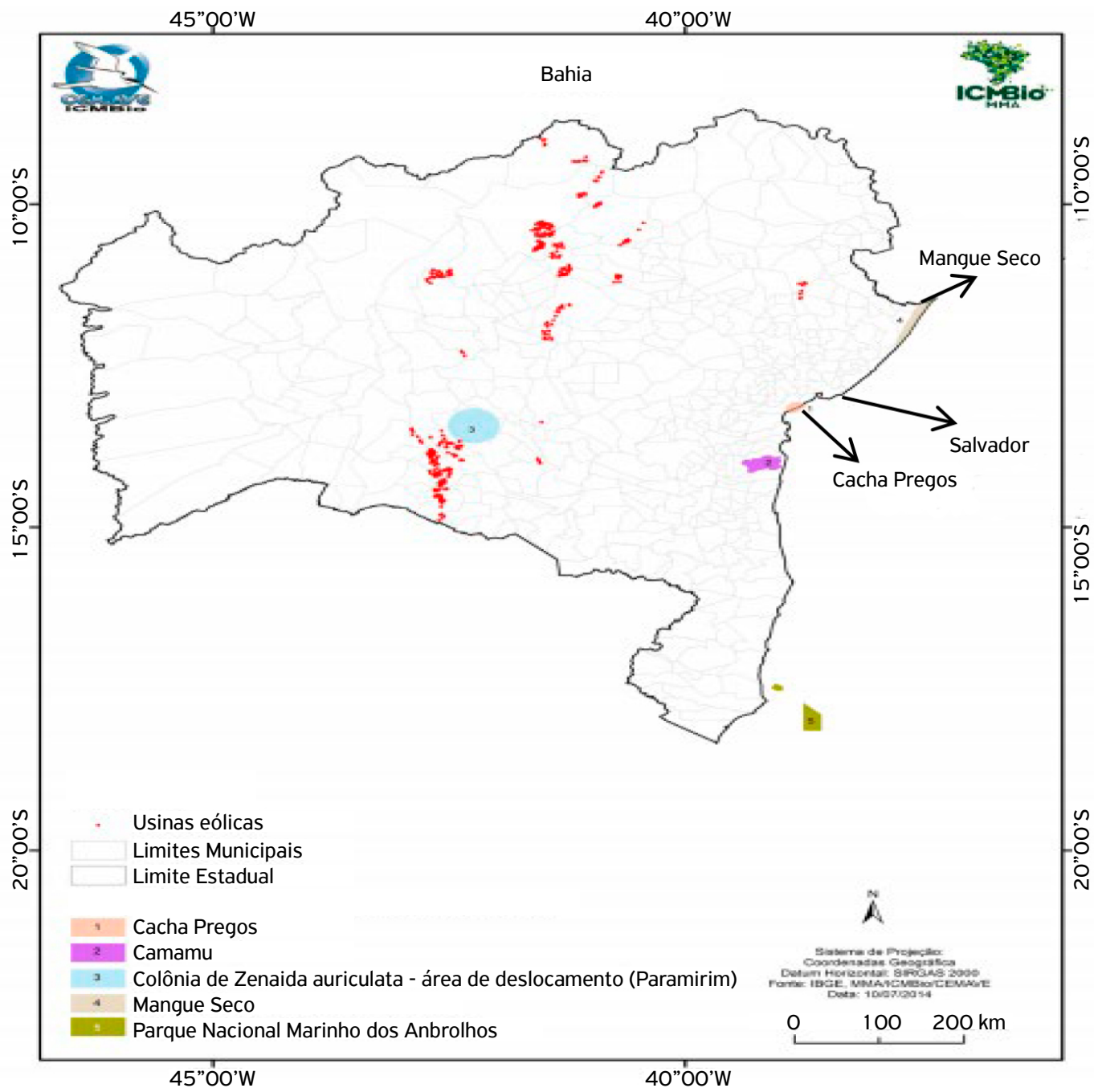

Figure 1. Location of study areas Mangue Seco and Cacha Pregos. Source: CEMAVE 2015.

Table 1. Number of analyzed birds at each breeding shack.

\begin{tabular}{|lc|}
\hline Number of birds & Number of samples \\
\hline 4 & 4 (all birds) \\
\hline 5 to 8 & 5 \\
\hline 9 to 13 & 6 \\
\hline 14 to 24 & 7 \\
\hline 25 to 78 & 8 \\
\hline 79 to 200 & 9 \\
\hline
\end{tabular}

Source: BRAZIL (2012).

Table 2. Number of birds used for sampling.

\begin{tabular}{lccc} 
Location/Year & 2013 & 2014 & Total \\
\hline Mangue Seco & 92 & 41 & 133 \\
\hline Cacha Pregos & 17 & 81 & 98 \\
\hline Total & 109 & 122 & 231 \\
\hline
\end{tabular}

Source: The authors. proceeding. All the samples were identified by property, then cooled, stored in an isothermal box, and sent to the Animal Health Laboratory, Agricultural Defense Agency of Bahia (LADESA-ADAB), and later on, to the National Agricultural Laboratory (LANAGRO) in Campinas, followed by the sampling's survey. During the task of cloacal/ tracheal swabs and blood serum collection, all measures of team protection were taken with the usage of individual protection equipment - such as disposable coveralls, eye and airways protective masks, and disposable gloves.

\section{Laboratorial analysis and statistics}

The serum samples were submitted to an indirect immunoenzymatic trial (ELISA) for profiling evaluation of behavioral answers according to the procedure determined by the manufacturer of the kit (IDEXX). The real-time polymerase chain reaction (PCR) technique was performed on LANAGRO and followed the OIE's 2013 recommended standards. 


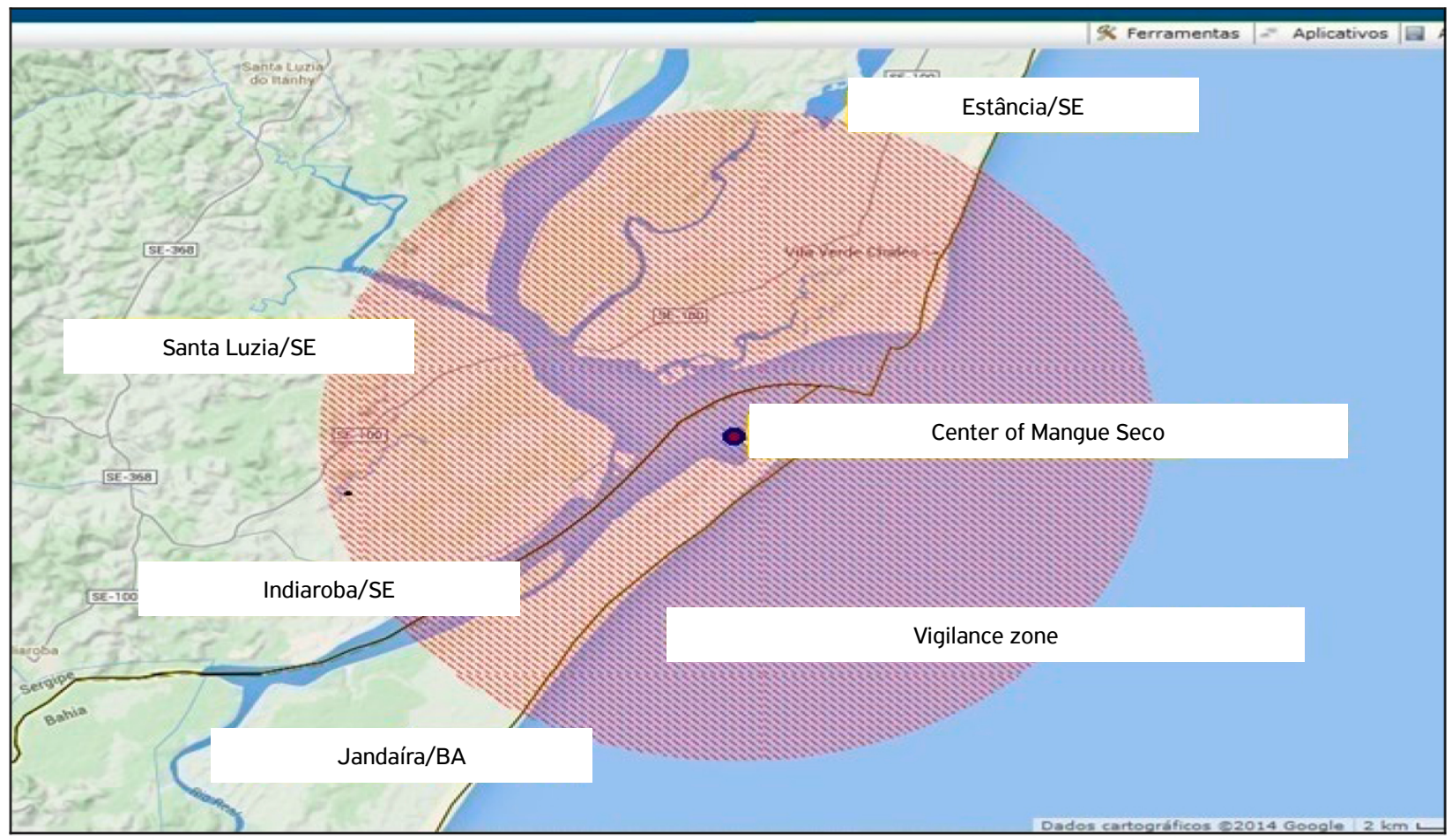

Figure 2. Vigilance zone of Mangue Seco/BA. This area, besides the mangrove, also comprehends the state of Sergipe.

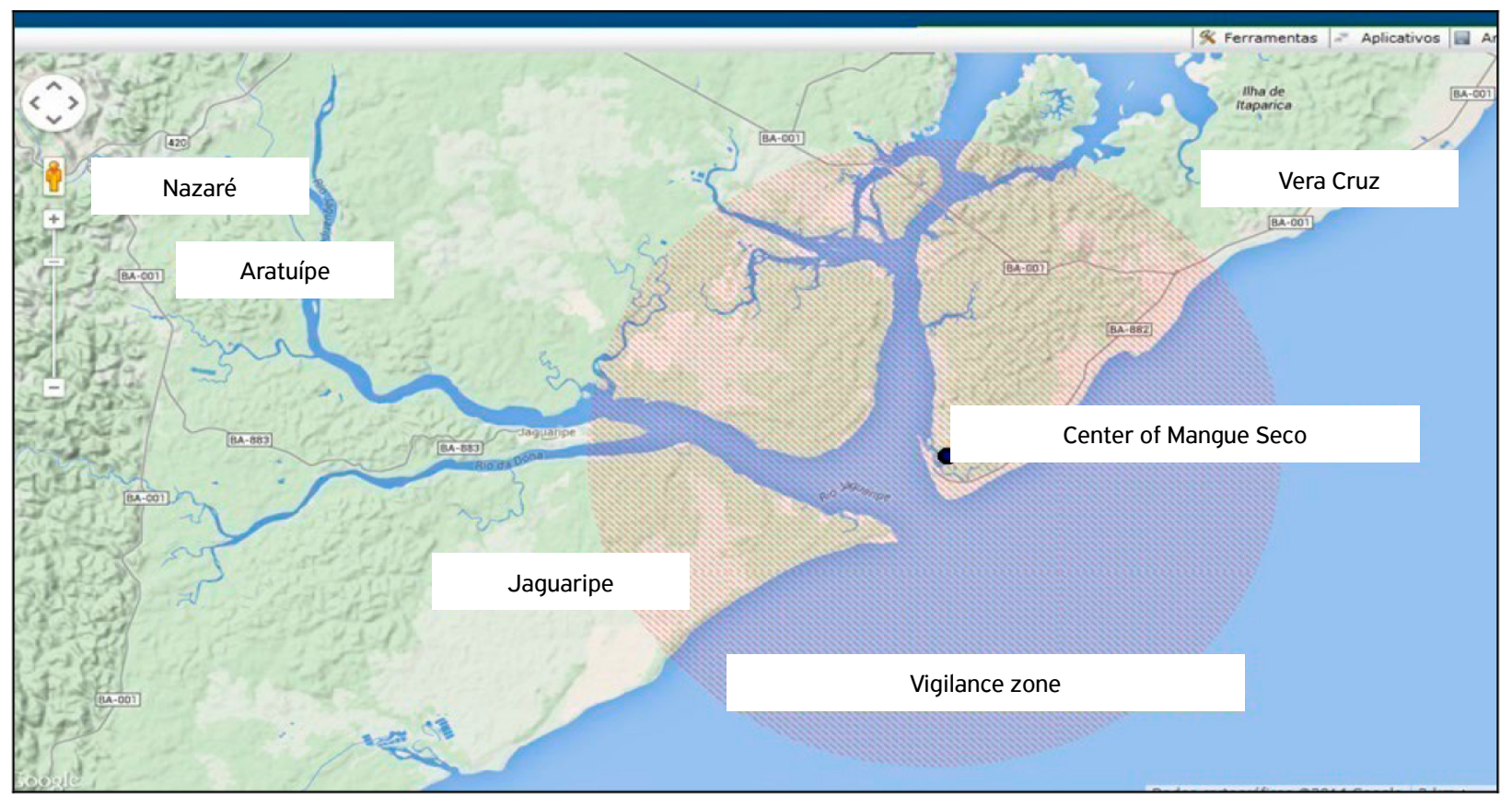

Figure 3. Vigilance zone of Cacha Pregos/BA. The epidemiological surveillance zone of the present study includes the Vera Cruz region with the city of Jaguaripe.

The statistical analysis was calculated using xChek software. The calculation of Newcastle's antibody title frequency was correlated with the reading of samples and reading of controls and established the antibody concentration from this correlation. Such a program validates the test when the difference between the average of positive control and the average of the negative control is bigger than 0.075 and the medium absorbency of the negative control is less or equal to 0.150 . The optical density (OD) was measured with an absorbance of $650 \mathrm{~nm}$ of wavelength, as specified on the antibody detection kit against NCD virus from IDEXX. 


\section{RESULTS}

Analysis of the epidemiologic questionnaires applied between 2013 and 2014 showed that in both sites, all investigated breeding shacks are for subsistence, that is, the birds live closely to residents; there are no hygiene and cleanliness principles, without sanitary control, the birds live in freedom over the mangrove and at the village, getting into direct contact with the migratory birds and other animal species, such as bovine, swine and equine. The biggest part of bird commerce is in the very region, excepting the Cacha Pregos epidemiologic unit, which has $8 \%$ of its commerce with other regions. It can be perceived that, although there is a prevalence of internal commerce, none of the units use the animal transport guidelines (ATG), as described in Table 3.
From the georeferencing of Mangue Seco and Cacha Pregos in a 25 kilometers radius, the two vigilance zones of the epidemiologic units were obtained: the Mangue Seco epidemiologic unit, formed by an area partially located at the cities of Estância, Santa Luzia and Indiaroba in Sergipe and in an area of Jandaíra city in Bahia, at the Real River delta as shown in Figure. 2. And the epidemiologic unit of Cacha Pregos, formed by an area partially located at the cities of Vera Cruz, Aratuípe and Jaguaripe, located at the Jaguaripe river as shown in Figure 3.

The village of Coqueiro was identified in the vigilance zone of Mangue Seco, distant 7 kilometers from center of Mangue Seco. Access to the villages of Mangue Seco and Coqueiro can occur by boat through the Real River (Pontal district/Sergipe) or by off-road car through Blue Coast beach/Bahia (Fig. 4).

Table 3. Sanitary profile of breeding shacks at the migratory sites of Mangue Seco and Cacha Pregos, Bahia, 2013 and 2014.

\begin{tabular}{lcccc} 
& \multicolumn{2}{c}{ Mangue Seco } & \multicolumn{2}{c}{ Cacha Pregos } \\
\cline { 2 - 3 } Indicators & $\mathbf{N}$ & $\%$ & $\mathbf{N}$ & $\%$ \\
\hline Presence of other animals at the property & $42(42)$ & 100 & $25(25)$ & 100 \\
\hline Internal bird commerce & $42(42)$ & 100 & $25(23)$ & 92 \\
\hline External bird commerce & $42(0)$ & 0 & $25(02)$ & 8 \\
\hline ATG use & $42(0)$ & 0 & $25(0)$ & 0 \\
\hline Subsistence breeding shacks & $42(42)$ & 100 & $25(25)$ & 100 \\
\hline Sanitary emptiness not realized & $42(42)$ & 100 & $25(25)$ & 100 \\
\hline Birds' vaccination not realized & $42(42)$ & 100 & $25(25)$ & 100 \\
\hline Contact with migratory birds & $42(42)$ & 100 & $25(23)$ & 92 \\
\hline Birds' disposal in common trashes & $42(42)$ & 100 & $25(13)$ & 52 \\
\hline
\end{tabular}

ATG: animal transport quidelines. Source: The authors.

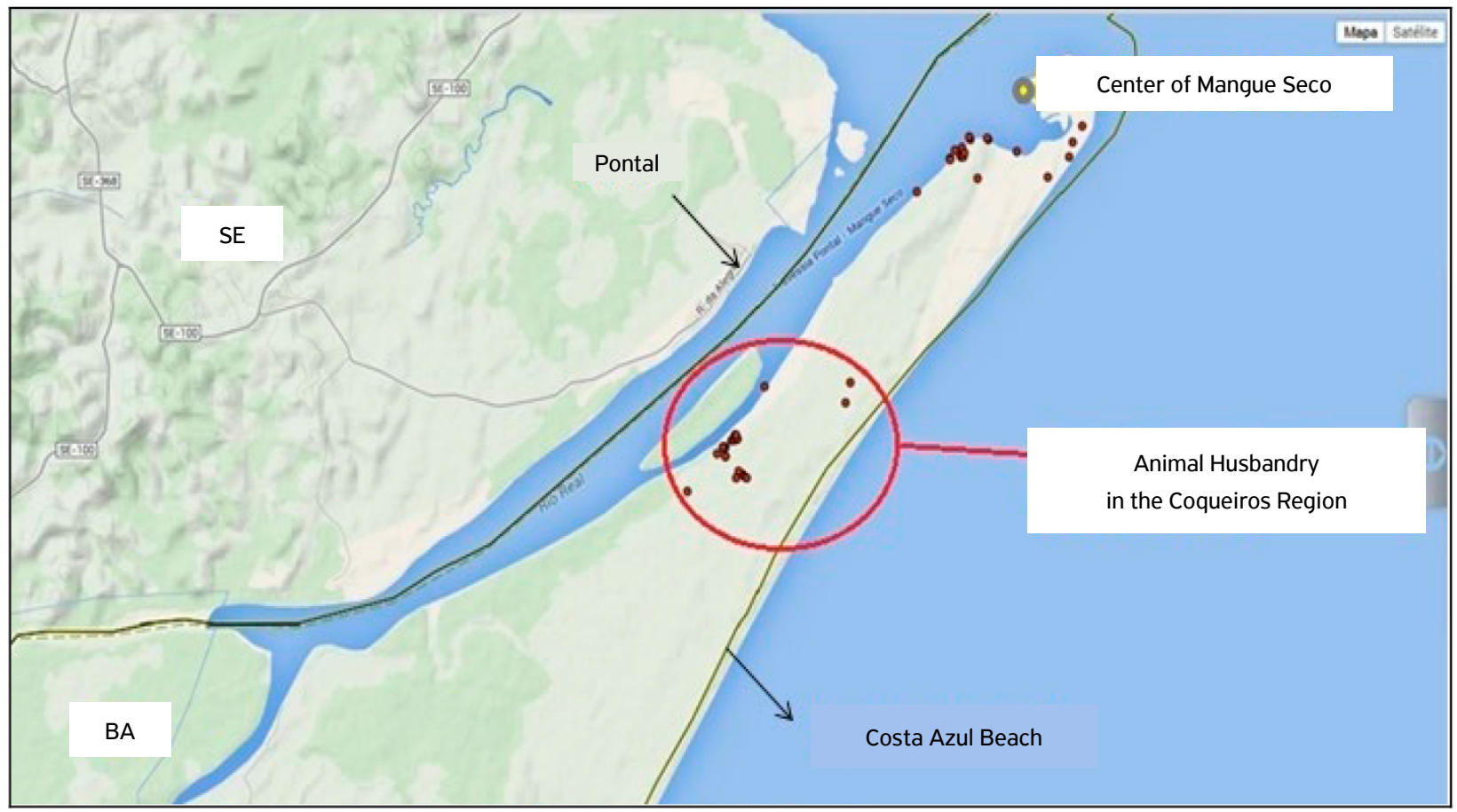

Figure 4. Registered and georeferenced breeding shacks at Mangue Seco migratory birds landing sites. Demonstration of access to these areas. 
The data obtained with georeferencing made possible that following MAPA's recommendations of a 25-kilometers radius from the studied vigilance zone identified that the landing units of migratory birds at Mangue Seco region does not limit itself to the state of Bahia, reaching the cities of Estância, Santa Luzia and Indiaroba in the state of Sergipe. The same way was observed in Cacha Pregos, where the area of vigilance comprehends beyond Vera Cruz the cities of Aratuípe and Jaguaripe in Bahia.

Regarding the submission of serologic proof, 152 samples were found reactive for NCD between 2013 and 2014. In 2013, Mangue Seco showed reactive samples, differently from Cacha Pregos where all the samples were negative. In 2014, there was a percentual increase of NCD-reactive samples by $63.4 \%$ at Mangue Seco and by $88.9 \%$ for Cacha Pregos, Table 4 .

The cloacal and tracheal swab samples were submitted to a cell culture test for isolation, at which the virus and its varieties were not found. These samples were also submitted to a confirmatory test through the molecular tool. All the submitted samples did not show amplification to the real-time PCR test.

\section{DISCUSSION}

The monitoring of landing sites for migratory birds involved educative actions, which allowed to comprehend the sanitary situation of backyard breeding shacks. The lack of knowledge of the local population, especially the bird owners, about the preventive measures of NDV entrance, the registry of contact between migratory and savage birds with poultry, birds discharge at public garbage and inadequate conditions of management were the main indicators evaluated and fundamental to define the sanitary profile of the breeding shacks.

There were no commercial farms around the $10 \mathrm{~km}$ area of the migratory site, a fact that demonstrates the lack of the possibility of vaccine virus circulation. The execution of epidemiologic vigilance proceedings at landing sites of migratory birds, including educational activities, are quintessential measures that need to be periodically revised and updated following national and international epidemiologic scenario changes or new scientific evidence as to control and prevention of NCD. The educational diagnostic is largely used in sanitary education actions as a way of promoting consciousness and change of behavior towards the animals' sanitary management (RIBEIRO, 2000). Given the situation found, the sanitary education activities were important allies during the research. The focus on preventive measures of NCD and other infirmities performed in public schools, through the distribution of guideline flyers and folders, brought in positive results as to the commitment and consciousness of the population at both localities.

The collection of information referring to georeferencing of backyard breeding and the risk and access points to Mangue Seco and Cacha Pregos sites, showed the spatial dimension of the researched area and were fundamental inside the investigative process. The stored information on the epidemiologic data in both researched units was essential to prioritize measures of orientation, prevention and control, which will proportionate better quality of epidemiologic vigilance. The inclusion and development of new tools for spatial analysis will allow the restraint, in a fast manner, of the NCD focuses or any other infirmity of interest to sanitary animal defense, if it were to happen. GIOTTO (2009) used the spatial analysis through geoprocessing techniques to evaluate NCD's dispersion possibilities to aviary production areas of Rio Grande do Sul, showing that only the traffic related to the technical visits and ration trucks at the production units are factors that can unleash a disease outbreak in other localities, and the faster a definitive diagnostic is obtained and the restraint measures are set in place, smaller the probability of spreading the disease.

The spatial characterization of the distribution of high-risk properties for a compulsory notification infirmity is extremely opportune because, aside from the fact that those properties demand active and continuous vigilance of the official veterinary service, it allows the establishment of preventive sanitary programs in the regions considered to be of a higher probability of infirmity occurrence. In this work, it was realized that other municipalities of Sergipe, as in the state of Bahia itself, also represent areas of risk and require studies as landing units for migratory birds. The development of monitoring and vigilance systems allows capillarity increment of the veterinary attention system, with efficiency and efficacy earnings derived from preventive actions executed. Such systems can promote the

Table 4. Demonstrative of processing results of samples through the ELISA technique.

\begin{tabular}{|c|c|c|c|c|c|c|c|c|}
\hline \multirow{3}{*}{ Processed Samples } & \multicolumn{4}{|c|}{2013} & \multicolumn{4}{|c|}{2014} \\
\hline & \multicolumn{2}{|c|}{ Mangue Seco } & \multicolumn{2}{|c|}{ Cacha Pregos } & \multicolumn{2}{|c|}{ Mangue Seco } & \multicolumn{2}{|c|}{ Cacha Pregos } \\
\hline & $\mathbf{N}$ & $\%$ & $\mathbf{N}$ & $\%$ & $\mathbf{N}$ & $\%$ & $\mathbf{N}$ & $\%$ \\
\hline Positive & 54 & 58.7 & ----- & ---- & 26 & 63.4 & 72 & 88.9 \\
\hline Negative & 38 & 41.3 & 17 & 100 & 15 & 36.6 & 9 & 11.1 \\
\hline Total & 92 & 100.0 & 17 & 100 & 41 & 100.0 & 81 & 100.0 \\
\hline
\end{tabular}

Source: The authors 
quality and accessibility of data, allowing public and private managers to perform customized analyses that bring more efficiency and efficacy to actions in animal health (DUTRA, 2007; TODESCHINI, 2010).

In the serologic approach performed in breeding shacks, the higher rates of animals reactive to NDV were observed due to infection with the virus of a lentogenic strain of low pathogenicity, suggesting that the birds are immune to the disease, being exposed, more than once, to NDV. At Cacha Pregos the presented positivity can be related to the contact with migratory birds as well as to the acquisition of birds from the aviary pole of Feira de Santana, city near Cacha Pregos. The serologic research at backyard chicken breeding shacks and ostrich related by SALES (2007), FERNANDES et al. (2009) and MATTOS (2013), at the Feira de Santana/Bahia region, showed the presence of antibodies against the Newcastle disease virus, even without any report of the birds' vaccination, strengthening the hypothesis that the birds got in contact with the virus (low-virulence strains), representing a risk factor for the poultry culture at the studied region. Nonetheless, the RT-PCR and viral isolation results were negative, proving that the birds were not eliminating the virus at the moment of sample collection. In Mangue Seco, the birdkeepers use their birds for squad reposition or commercialization with neighbors similar to the findings of MARKS et al. (2014) in a serum-epidemiologic survey realized for NDV in subsistence breeding shacks located in wintering areas of migratory birds of the south region of Brazil. Prevalence of NDV raised when the producers used their reposition birds to establish their flocks.

Migration patterns of savage geese provide more evidence that it is possible that the main areas of rest and wintering of aquatic migratory birds are important at the transmission of aviary diseases in the same species and between different species; therefore, representing risks to the poultry industry because these birds can be involved in the spreading of viral diseases, specifically the NCD (MÜLLER et al., 1999), which strengthen the importance of keeping an efficient epidemiologic vigilance system at both bird landing sites of Mangue Seco and Cacha Pregos due to the proximity to the poultry pole regions of Feira de Santana and Alagoinhas. Poultry is of huge importance to Bahia, mainly for its generation of socioeconomic benefits, and an outbreak of this disease would represent a risk to the regional and national economy, reflecting negatively on the levels of consumption of quality protein economically accessible to the population.

\section{CONCLUSIONS}

An epidemiological link can be established between migratory birds and backyard poultry, which also makes it possible to understand a relationship between the routes used by migratory birds and the number of Newcastle disease cases. Birds live in contact with residents; there are no principles of hygiene and cleanliness. Without control sanitary, domestic birds live freely in the mangrove and in the village, coming into contact with migratory birds and other animal species such as cattle, pigs and horses.

Georeferencing found that other areas, such as the municipalities of Aratuípe and Jaguaripe in Bahia and Estância, Santa Luzia and Indiaroba in Sergipe, can be investigated as possible risk areas for this disease. Due to the high percentage of animals reacting to the ELISA serological test in both units studied, the presence of circulating Newcastle virus is suggested, since there was no record of mortality and the birds did not show clinical signs of the disease. The negative results of PCR and viral isolation make it possible to understand that possibly the birds were not eliminating the virus at the time of of at the time of blood withdrawal.

ACKNOWLEDGEMENTS: To the Community of Migratory Bird Landing Units.

FUNDING: This study was financed in part by the Coordenação de Aperfeiçoamento de Pessoal de Nível Superior - Brasil (CAPES) Finance Code 001.

CONFLICTS OF INTEREST: All authors declare that they have no conflict of interest. ETHICAL APPROVAL: This research was submitted for approval by the Ethics Committee on the Use of Animals (2011-2012) of the Universidade Federal do Recôncavo Bahia. However was its approval is unnecessary, because the samples were collected by a State agency authorized to carry out the procedures of this work (Bahia Agricultural Defense Agency).

AVAILABILITY OF DATA AND MATERIAL: All data generated or analyzed during this study are included in this published article.

AUTHORS' CONTRIBUTIONS: Conceptualization: Cerqueira, R.B.; Souza, V.M.M.; Ribas, J.R.L.; Ferrão, I.S. Methodology: Ribas, J.R.L.; Cerqueira, R.B.; Souza, V.M.M.; Santos M.P.J.B.; Leal, R.F.; Prinz, M. S. Project administration: Cerqueira, R.B. Supervision: Cerqueira, R.B. Writing — original draft: Fernandes, B.P; Prinz, M. S. Writing - review \& editing: Fernandes, B.P; Prinz, M. S. 

REFERENCES

ALEXANDER, D.J.; JONES, R.C. Newcastle disease, other avian Paramyxoviruses and Pneumovirus infections. In: SAIF, Y.M. (ed). Diseases of Poultry. 11 th. Ed. Ames: Iowa State University Press, 2003. p.63-92.

BRAZIL. Ministry of Agriculture, Livestock and Supply, Secretary of Agropecuary Defense, Department of Animal Health. Technical Note CSA 16/2012 - Epidemiologic Vigilance for IA and NCD at Migratory Bird Sites, 2012. Available from: https://www.associacoes.org.br/component/easyfolderlistin gpro/?view $=$ download\&format $=$ raw\&data $=$ eNpFULFOwzAQ_ ZWT97ZxgBTcyaJFqgRZilira3JJLcVJZLulEuJrmBiY2BjJj2HX qZh87929e_eMgnPxZkUmWNU1 JRm2sOJWMI2OjElboJ9gBOsmDkRKsOTSqg9k3b94Lth2e-bGVUHaoqZcMBPBwpNFVpVsoUQSRYaaHtO-tK9vBJtxmMBy9bDaSJD5-kk-zvgODRxVZBFkqzQ2Hssj2dGpUg1 dnOb-srxzCM_DZzGF9veHZ5 M04enkRdWqGT7aQiGQhs3w5VRnQavaoBu-TVwwPRqEtQSC ZX4f1IOJRIwnN1 Z9WY1 J6dQrE_xjD07zoXNY7DW $1 \mathrm{fnp3Zu-}$ -8wtBROWv8IZ--7rq68Xe-_wGJOXo3. Access on: 3 Oct. 2020.

CEMAVE 2015, v. 8, n. 2 Available from: http://ornithologia. cemave.gov.br/index.php/migrante/article/download/261/168. Access on: 21 Oct. 2020

DUTRA, M.G.B.; SANTOS, D.V. Caracterização das propriedades rurais para o risco de introdução do vírus da febre aftosa no rebanho gaúcho, Veterinária em Foco, Canoas, v.5, n. 1, p.38-43, 2015. Available from: https://www.agricultura.rs.gov.br/upload/ arquivos/201611/25103957-see-artigo-15caracterizacaodas-propriedades-rurais-para-o-risco-de-introducao-do-virusda-febre-aftosa-no-rebanho-gaucho.pdf. Access on: 3 Oct. 2020.

FERNANDES, L.M.B. et al. Soroepidemiologia da doença de Newcastle em plantéis de avestruzes dos Estados da Bahia e de São Paulo. Ciência Rural, Santa Maria, v.40, n. 1, p.135-140, 2009. https://doi.org/10.1590/SO103-84782009005000248

GIOTTO, D.B. Simulação da disseminação da doença de Newcastle relacionando o trânsito de veículos entre empresas integradoras e unidades de produção de frangos de corte. 2009. Dissertation (Master in Veterinary Sciences) - Universidade Federal do Rio Grande do Sul, Porto Alegre, 2009. Available from: https://www. lume.ufrgs.br/bitstream/handle/10183/16235/000698800. pdf? sequence $=1$ \& isAllowed $=y$. Access on: 3 Oct. 2020 .

MARKS, F.S.; RODENBUSCH, C.R.; OKINO, C.H.; HEIN, H.E.; COSTA, E.F.; MACHADO, G.; CANAL, C.W.; BRENTANO, L.; CORBELLINI, L.G.; Targeted survey of Newcastle disease virus in backyard poultry flocks located in wintering site for migratory birds from Southern Brazil. Preventive Veterinary Medicine, Berlin, v.116, n. 1-2, p.197202, 2014. https://doi.org/10.1016/j.prevetmed.2014.06.001
MATTOS, A.B. Sorologia e pesquisa viral para a doença de Newcastle em galinhas de quintal na microrregião de Feira de Santana. 2013. Dissertation (Master in Agriculture) - Universidade Federal do Recôncavo da Bahia, Cruz das Almas, 2013. Available from: http://repositorio.ufrb.edu.br/ bitstream/123456789/823/1/DISSERTAO\%2OADRIANA\%20 BATISTA\%2OMATTOS\%281\%29\%20Copy.pdf. Access on: 21 Sep. 2020.

MÜLLER, T.; HLINAK, A.; MÜHLE, R.U.; KRAMER, M.; LIEBHERR, H.; ZIEDLER, K.; PFEIFFER, D.U. A Descriptive Analysis of the Potential Association between Migration Patterns of Bean and White-Fronted Geese and the Occurrence of Newcastle Disease Outbreaks in Domestic Birds. Avian Diseases, Jacksonville, v.43, n.2, p.315-319, 1999. https://doi. org/10.2307/1592623

World Organisation for Animal Health (OIE). Terrestrial animal health code. 2019 Available from: http://www.oie.int/index. php? id $=169 \& \mathrm{~L}=0 \&$ htmfile=chapitre_surveillance_general.htm. Access on: 3 Oct. 2020.

RIBEIRO, V.F. Controle e Erradicação da brucelose bovina. 2000. Monography (Specialization in Animal Sanity) - Universidade de Santa Catarina, Lages, 2000.

SALES, T.S.; HERVAI, E.F.G.; CÉSAR, A.E.R.; RAMOS, I.; BATINGA, T.B.; SILVA, P.S.; MAIA, P.C.C.; FERNANDES, L. Títulos de anticorpos contra o vírus da doença de Newcastle em três diferentes sistemas de criação avícola na região de Feira de Santana - Bahia. Revista Brasileira de Saúde e Produção Animal, Ondina, v.8, n.4, p.386-393, 2007. Available from: https://repositorio.ufba.br/ri/bitstream/ ri/1937/1/847-3327-2-PB.pdf. Access on: 21 Sep. 2020.

THOMAZELLI, L.M. Vigilância Epidemiológica do Vírus da Doença de Newcastle em Aves Domésticas e Selvagens pelo Método de Real Time PCR. 2009. Thesis (Doctorate in Biotechnology) - Universidade de São Paulo, São Paulo, 2009. Available from: https://www.teses. usp.br/teses/disponiveis/87/87131/tde-23072009-171131/ publico/LucianoMatsumiyaThomazelli_Doutorado.pdf. Access on: 21 Sep. 2020.

TODESCHINI, B. Foco epidemiológico nos dados da tuberculose e brucelose visando a implementação de um sistema informatizado de monitoramento e vigilância. 2010. Dissertation (Master in Veterinary Sciences) - Universidade Federal do Rio Grande do Sul, Porto Alegre, 2010. Available from: https://www.lume. ufrgs.br/bitstream/handle/10183/29066/000775159. pdf? sequence $=1$. Access on: 21 Sep. 2020 . 